\title{
Chemical Composition and Metabolizable Energy Values of Corn Germ Meal Obtained by Wet Milling for Layers
}

\section{-Author(s)}

Albuquerque CS

Rabello CBV

Santos MJB'

Lima MB"

Silva EPI

Lima TS'

Ventura DP

Dutra Jr WM

Animal Science Department, Universidade Federal Rural de Pernambuco (UFRPE) Recife, PE. 52171-900, Brazil.

" Department of Animal Science, School of Agricultural and Veterinary Sciences, Universidade Estadual Paulista Júlio de Mesquita Filho, Jaboticabal, São Paulo, Brazil

\section{Mail Adress}

Corresponding author e-mail address Carlos Bôa-Viagem Rabello

Dom Manoel de Medeiros, s/n, Dois Irmãos

- 52171-900 - Recife, Brazil. Tel.: +55

8196923237, fax: +55 81 81-3320-6555

E-mail address: cbviagem@dz.ufrpe.br

\section{-Keywords}

Amino acids, coefficient of digestibility, metabolizable energy.

\section{ABSTRACT}

An experiment was carried out to determine the chemical composition, metabolizable energy values, and coefficients of nutrient digestibility of corn germ meal for layers. The chemical composition of corn germ meal was determined, and then a metabolism assay was performed to determine its apparent metabolizable energy (AME) and apparent metabolizable energy corrected for nitrogen (AMEn) values and its dry matter and gross energy apparent metabolizability coefficients (CAMDM and CAMGE, respectively). In the 8-day assay (four days of adaptation and four days of total excreta collection), 60 29-week-old white Lohman LSL layers were used. A completely randomized experimental design, with three treatments with five replicates of four birds each, was applied. Treatments consisted of a reference diet and two test diets, containing 20 or 30\% corn germ meal. Results were submitted to analysis of variance and means were compared by the Tukey tests at 5\% probability level. The chemical composition of corn germ meal was: $96.39 \%$ dry matter, $49.48 \%$ ether extract, $1.87 \%$ ashes, 7243 kcal gross energy $/ \mathrm{kg}, 11.48 \%$ protein, $0.19 \%$ methionine, $0.21 \%$ cystine, $0.48 \%$ lysine, $0.40 \%$ threonine, $0.72 \%$ arginine, $0.35 \%$ isoleucine, $0.83 \%$ leucine, $0.57 \%$ valine, and $0.37 \%$ histidine, on as-fed basis. There were no statistical differences in AME, AMEn, CAMDM, and CAMGE values with the inclusion of 20 and $30 \%$ corn germ meal in the diets. On dry matter basis, AME, AMEn, CAMDM, and CAMGE values of corn germ meal were: 4,578 and 4,548 kcal/kg, 4,723 and 4,372 kcal/kg, 64.95 and $61.86 \%$, respectively.

\section{INTRODUCTION}

Compared with other animal industry, poultry production presents higher productivity, shorter production cycles, and cheaper protein offer. Research on new technologies has significantly promoted the development of productivity of the poultry industry. In particular, studies on alternative feedstuffs have allowed considerable reduction in production costs. Although most poultry feeds are based on corn and soybeans, regions that do not produce these ingredients have higher production costs, and need to seek alternatives.

Corn germ meal (CGM) is a co-product of corn wet milling and may be used as an alternative feedstuff for poultry. Corn can generate several co-products, and the corn processing industry may add value to corn through wet or dry milling.

In Brazil, it is estimated that there are 10,000 tons of CGM available annually for oil extraction or to be used directly in animal feeds (Abimilho, 2010). Up to $20 \%$ defatted corn germ can be added to broiler diets without any damage to performance (Brunelli et al., 
2006). It was observed that the inclusion of up to $50 \%$ CGM derived from dry milling did not affect layer performance (Brito et al., 2005).

When obtained by wet milling with no oil extraction, CGM has high ether extract level (EE). Studies carried out by Lima (2007) and Lima et al. (2012) show that EE content in CGM ranges between 46 and $60 \%$, providing it with a huge energy potential, with apparent metabolizable energy (AME) values of $2232-4800 \mathrm{kcal} /$ $\mathrm{kg}$. It should be mentioned, however, that not only EE content affects the potential of energy utilization, but also animal class and bird age. Therefore, CGM may potentially replace oil in feeds, increasing their energy density. In addition, the use of feedstuffs rich in fatty acids has the beneficial effect of reducing feed passage rate through the gastrointestinal tract (Andreotti et al., 2004), which increases the digestibility of feedstuffs, increasing their metabolizability coefficients. Another important advantage of the use of oil-rich ingredients in the diet is the improvement of pellet quality, particularly due to mass aggregation (Penz Jr. \& Vieira, 1992).

Considering that there are few studies on corn germ meal obtained by wet milling, and that most of studies were carried out with defatted CGM, the objective of the present study was to determine the chemical composition and metabolizable energy values of full-fat corn germ meal obtained by wet milling for layers.

\section{MATERIALS AND METHODS}

\section{Location and chemical analyses}

The experiment was carried out in the experiment layer house of the Laboratory of Poultry Research (Laboratório de Pesquisa com Aves, LAPAVE) of the Department of Animal Science of Universidade Federal Rural de Pernambuco, Brazil.

The evaluated CGM was obtained from the company Corn Products do Brasil, located in Cabo de Santo Agostinho, state of Pernambuco, Brazil. A representative sample was collected and submitted to the laboratory of nutrition of the Department of Animal Science for analyses. The following analyses were performed: dry matter, crude protein, EE, and ashes, using the methods described by Silva \& Queiroz (2006). Amino acid profile was determined by the company Evonik and gross energy content was analyzed in a calorimetric bomb by Universidade Federal de Viçosa.

\section{Birds and Experimental procedure}

A metabolism assay was carried out with commercial layers according to the methodology described by Hill \& Anderson (1958). Sixty 26-week-old Lohman LSL layers were distributed according to a completely randomized experimental design, with three treatments with five replicates of four birds each. Treatments consisted of a reference diet, a mixture of $80 \%$ of the reference diet $+20 \%$ CGM (CGM20\%), and a mixture of $70 \%$ of the reference diet $+30 \%$ CGM. The reference diet was formulated according to the recommendations of the Brazilian Tables for Poultry and Swine of Rostagno et al. (2005), as shown in Table 1.

Table 1 - Ingredients and nutritional and energy compositions of the reference diet.

\begin{tabular}{lc}
\hline Ingredients & $\%$ \\
\hline Corn & 60.047 \\
\hline Soybean meal & 26.414 \\
\hline Calcitic limestone & 9.837 \\
\hline Dicalcium phosphate & 1.375 \\
\hline Salt & 0.334 \\
\hline Soybean oil & 1.573 \\
Mineral, vitamin, and amino acid supplement ${ }^{1}$ & 0.400 \\
\hline DL-Methionine 99 & 0.020 \\
\hline Total & 100.000 \\
\hline Nutritional and energy composition ${ }^{2}$ & \\
\hline Apparent metab. energy, kcal/kg & 2.700 \\
\hline Crude protein, \% & 17.00 \\
\hline Calcium, \% & 4.200 \\
\hline Available phosphorus \% & 0.350 \\
\hline Digestible methionine + cystine, \% & 0.610 \\
\hline Digestible methionine \% & 0.368 \\
\hline Digestible lysine \% & 0.800 \\
\hline Potassium, \% & 0.665 \\
\hline Sodium, \% & 0.150 \\
\hline
\end{tabular}

'Mineral, vitamin, and amino acid supplement for layers (composition/kg product): Vit. A: 2,000,000 IU, Vit. D3: 575,000 IU, Vit. E:3,750 mg, folic acid: 125 mg, calcium pantothenate: $1,750 \mathrm{mg}$, biotin: $3.75 \mathrm{mg}$, niacin: $5.000 \mathrm{mg}$, pyridoxine: $425 \mathrm{mg}$, riboflavin: 750 mg, thiamine: 50mg, Vit. K3: 250 mg, Vit.B12: 2.500 mcg, choline: 52.19g, selenium: $62.5 \mathrm{mg}$, iron: 7,500mg, copper: 19,750 mg, manganese: 15,000 mg, zinc: $15,000 \mathrm{mg}$, iodine: $250 \mathrm{mg}$, methionine: $247.5 \mathrm{~g}$, colistin: $2,000 \mathrm{mg}$. ${ }^{2}$ Values calculated according to the Tables of Rostagno et al. (2005).

Birds were housed in galvanized iron-mesh cages $(50 \times 50 \times 45 \mathrm{~cm})$, with capacity of four birds per cage. Trays lined with black plastic canvas were placed under the cages for excreta collection. The eightday experimental period was divided in four days of adaptation to the diets and four days of excreta collection.

Powdered ferric oxide at $1 \%$ was added to the diets as fecal marker to determine the beginning and end of 
the collection period. Water and feed were offered ad libitum. A lighting program of 17 hours of natural and artificial light was adopted.

Excreta were collected twice daily, at 08:00 and 16:00. Excreta were placed in plastic bags, duly identified, weighed, and stored in a freezer at $-20^{\circ} \mathrm{C}$ until the end of the experiment to prevent fermentation. At the end of the experiment, excreta were thawed and homogenized per experimental unit. Aliquots of approximately $400 \mathrm{~g}$ were removed per unit, pre-dried, ground in a knife mill, and submitted to the Laboratory for analyses.

\section{Analytical parameters \\ procedures and evaluated}

Feed and excreta were submitted to the Animal Nutrition Laboratory of the Department of Animal Science of Universidade Federal Rural de Pernambuco to determine dry matter, crude protein, and ether extract contents, according to the previously mentioned methods.

Apparent metabolizable energy (AME) and apparent metabolizable energy corrected for nitrogen balance (AMEn) of the experimental diets and CGM were determined according to the equations proposed by Matterson et al. (1965). The coefficients of apparent metabolizability of dry matter (CAMDM), gross energy (CAMGE), and ether extract (CAMEE) were determined according to the following equations: $\mathrm{CAMGE}=$ (AMEn/GE) x 100, CAMDM = feed intake $-[$ (excreta)/ feed intake)] $\times 100$, on dry matter basis.

\section{Statistical Analysis}

Results were submitted to analysis of variance and means were compared by the test of Tukey at 5\% probability level, using SAS package (SAS, 2004).

\section{RESULTS}

Humidity value of CGM was low (3.61\%). Crude protein, ether extract, and ash average values of CGM were $11.48,49.48$, and $1.87 \%$, respectively (Table 2 ).

Mean amino acid values of CGM were $0.19 \%$ methionine, $0.21 \%$ cystine, $0.40 \%$ methionine+cystine, $0.48 \%$ lysine, $0.40 \%$ threonine, $0.72 \%$ arginine, $0.35 \%$ isoleucine, $0.83 \%$ leucine, $0.57 \%$ valine, $0.37 \%$ histidine, $0.45 \%$ phenylalanine.

The results showed that the dietary inclusion of CGM changed the chemical composition of the reference diet, increasing dry matter, ether extract, and gross energy contents, and reducing crude protein and ash contents (Table 3).
Table 2 - Dry matter, crude protein, ether extract, gross energy, ash, and amino acid values of full-fat corn germ meal.

\begin{tabular}{lc|cc}
\hline \multicolumn{2}{l|}{ Chemical composition } & \multicolumn{2}{c}{ Amino acid composition, \% } \\
\hline Humidity & 3.61 & Methionine & 0.19 \\
\hline Dry matter, \% & 96.39 & Cystine & 0.21 \\
\hline Crude protein, \% & 11.48 & $\begin{array}{c}\text { Methionine + } \\
\text { cystine }\end{array}$ & 0.40 \\
\hline Ether extract & 49.48 & Lysine & 0.48 \\
\hline Ashes, \% & 1.87 & Threonine & 0.40 \\
\hline Gross energy, kcal/kg & 7243 & Arginine & 0.72 \\
& & Isoleucine & 0.35 \\
& & Leucine & 0.83 \\
\hline
\end{tabular}

${ }^{1}$ Values analyzed by the company Evonik.

Table 3 - Dry matter, crude protein, ether extract, gross energy, ash, and amino acid values of the reference and experimental diets.

\begin{tabular}{lccc}
\hline \multirow{2}{*}{ Components, \% } & \multicolumn{3}{c}{ Experimental diet } \\
\cline { 2 - 4 } & Reference & 20\%CGM & $30 \%$ CGM \\
\hline Dry matter & 90.45 & 91.74 & 92.32 \\
\hline Crude protein & 16.67 & 15.40 & 14.82 \\
\hline Ether extract & 4.40 & 13.55 & 17.72 \\
\hline Ashes & 11.85 & 10.07 & 9.01 \\
\hline $\begin{array}{l}\text { Gross energy } \\
\text { (kcal/kg) }\end{array}$ & 4119 & 4757 & 5065 \\
\hline
\end{tabular}

Dry matter intake was statistically higher when layers were fed the reference diet compared with those fed the 20\% CGM and 30\% CGM, which in turn, were not different (90.2 and $95.0 \mathrm{~g} / \mathrm{bird} /$ day), as shown in Table 4.

Excreta dry matter was not influenced by the treatments. Layers fed the 30\%CGM diet presented higher EE intake ( $16.84 \mathrm{~g} / \mathrm{bird} /$ day) compared with the other treatments, followed by those fed the 20\%CGM diet $(12.22 \mathrm{~g} / \mathrm{bird} /$ day), and the reference diet (4.92 g/bird/day). Fecal EE content was statistically different among treatments, with the highest level obtained in the excreta of layers fed 30\% CGM (51.49 g/bird/day), followed by the $20 \%$ CGM and the reference diet, with 35.22 and $8.42 \mathrm{~g} / \mathrm{bird} /$ day, respectively. 
Table 4 - Mean dry matter (DM) and ether extract (EE) intake and excretion of the layers submitted to the different treatments.

\begin{tabular}{lcccccc}
\hline \multirow{2}{*}{ Parameters } & \multicolumn{4}{c}{ Experimental diet } & & \\
\cline { 2 - 4 } & Reference & $20 \%$ CGM & $30 \%$ CGM & & \\
\hline $\begin{array}{l}\text { DM intake, g/bird/ } \\
\text { day }\end{array}$ & 112.00 a & $90.20 \mathrm{~b}$ & $95.00 \mathrm{~b}$ & 9.28 & $* *$ \\
$\begin{array}{l}\text { DM excretion, g/ } \\
\text { bird/day }\end{array}$ & $21.04 \mathrm{a}$ & $19.70 \mathrm{a}$ & $21.17 \mathrm{a}$ & 8.16 & $\mathrm{~ns}$ \\
$\begin{array}{l}\text { EE intake, g/bird/ } \\
\text { day }\end{array}$ & $4.92 \mathrm{c}$ & $12.22 \mathrm{~b}$ & $16.84 \mathrm{a}$ & 8.55 & $* *$ \\
$\begin{array}{l}\text { EE excretion, g/ } \\
\text { bird/day }\end{array}$ & $0.84 \mathrm{c}$ & $3.25 \mathrm{~b}$ & $5.15 \mathrm{a}$ & 17.02 & $* *$ \\
\end{tabular}

Means followed by different letters in the same row are statistically different by the test of Tukey at $5 \%$ probability level.

${ }^{* *} p<0.01$

The reference diet presented statistically higher coefficients of metabolizability of all evaluated parameters compared with the other diets (Table 5).

Table 5 - Mean coefficient of apparent metabolizability of the dry matter, ether extract, gross energy, and apparent metabolizable energy (AME) and apparent metabolizable energy corrected for nitrogen balance (AMEn) values of the experimental diets, on dry matter basis.

\begin{tabular}{lllllll}
\hline \multirow{2}{*}{$\begin{array}{l}\text { Coefficient of } \\
\text { metabolizability, \% }\end{array}$} & \multicolumn{5}{c}{ Treatments } \\
\cline { 2 - 5 } & Reference & $20 \%$ CGM & $30 \%$ CGM & F \\
\hline Dry matter & $69.59 \mathrm{a}$ & $64.93 \mathrm{~b}$ & $64.37 \mathrm{~b}$ & 3.84 & 0.126 \\
\hline Ether extract & $82.85 \mathrm{a}$ & $71.18 \mathrm{~b}$ & $69.44 \mathrm{~b}$ & 4.84 & 20.42 \\
Gross energy & $78.34 \mathrm{a}$ & $73.39 \mathrm{~b}$ & $71.21 \mathrm{~b}$ & 3.80 & 8.33 \\
\hline AME (kcal/kg) & $3,226 \mathrm{a}$ & $3,491 \mathrm{~b}$ & $3,607 \mathrm{~b}$ & 3.73 & 11.55 \\
AMEn (kcal/kg) & $3,155 \mathrm{a}$ & $3,437 \mathrm{~b}$ & $3,536 \mathrm{~b}$ & 3.44 & 14.57
\end{tabular}

Means followed by different letters in the same row are statistically different by the $\mathrm{t}$ test at $5 \%$ probability level.

${ }^{* *} p<0.01$

The CAMDM results obtained for the reference, CGM20\%, and CGM30\% diets were 69.59, 64.93, and $64.37 \%$, respectively. There was no influence of the CGM20\% and CGM30\% diets on CAMDM, CAMEE, CAMGE, AME, or AMEn.

The study showed that increasing the dietary inclusion of corn germ meal from 20 to $30 \%$ did not affect CAMGE, CAMEE, AME, or AMEn values. Values of 64.93 and $62.53 \%$ were obtained for CAMGE and CAMEE, respectively (Table 6).
Table 6 - Mean coefficients of apparent metabolizability of dry matter (CAMDM) and of gross energy (CAMGE) and apparent metabolizable energy (AME) and apparent metabolizable energy corrected for nitrogen balance (AMEn) values of corn gluten meal, on dry matter basis.

\begin{tabular}{lccccc}
\hline \multirow{2}{*}{ Parameters } & \multicolumn{2}{c}{ Replacement levels } & & & \\
\cline { 2 - 3 } & $20 \%$ & $30 \%$ & Means & CV & F \\
\hline CAMDM, \% & 64.93 & 64.37 & 64.65 & 3.8 & NS \\
CAMGE, \% & 62.53 & 60.88 & 61.86 & 12.86 & NS \\
AMEn (kcal/kg) & 4,715 & 4,441 & 4,578 & 11.43 & NS \\
AMEn (kcal/kg) & 4,723 & 4,372 & 4,548 & 10.56 & NS
\end{tabular}

NS= non-significant

The obtained AMEn value of the evaluated CGM was $4,723 \mathrm{kcal} / \mathrm{kg}$, which is very close to the AME value of $4,715 \mathrm{kcal} / \mathrm{kg}$, demonstrating that birds were at zero nitrogen balance.

\section{DISCUSSION}

The CGM evaluated in this study derived from corn wet milling, aiming at extracting and processing starch for the food industry. Dry milling of corn, which objective is processing by-products for human consumption, is less efficient in separating corn fractions, and the resulting CGM contains less fat and consequently higher moisture. The low humidity value obtained in the evaluated CGM was low (3.61\%) due to its high EE content (49.48\%). Comparing with literature reports, this result is different than those obtained by Brum et al. (2000), Brito et al. (2005), and Brunelli et al. (2006) in defatted corn germ meal, of $11.17,10.00$, and $9.81 \%$, respectively, as well as by Rostagno et al. (2011), of $10.29 \%$.

The differences in crude protein levels and amino acid profiles are mainly related to CGM ether extract content. This shows processing does not have a strong influence on CGM composition, which in turn, depends on the corn from which it derived. Corn composition provides important information on the composition of its processed products and co-products.

The obtained crude protein value is consistent with those reported in literature of $10.88,9.81$, and $10.38 \%$ (Brito et al., 2005; Brunelli et al., 2006; Rostagno et al., 2011, respectively).

Average amino acid ratios in the evaluated CGM agree with the findings of Rostagno et al. (2011), but not with those of Brum et al. (2000) for CGM derived from dry milling, which were 0.19 and $0.25 \%$ methionine, 0.41 and $0.55 \%$ methionine+cystine, 0.45 and $0.42 \%$ lysine, 0.39 and $0.32 \%$ threonine, 0.65 
and $0.56 \%$ arginine, 0.33 and $0.24 \%$ isoleucine, 0.90 and $0.71 \%$ leucine, 0.50 and $0.38 \%$ valine, 0.31 and $0.26 \%$ histidine, and 0.43 and $0.36 \%$ phenylalanine, respectively. Tryptophan was not analyzed in the present study, but the authors above obtained a value of $0.09 \%$. In general, amino acid values presented in literature are consistent with the findings of this study and similar to those found in corn because CGM crude protein content is close or higher than that found in Brazilian corn.

The following values were reported for EE content of CGM derived from dry milling for starch extraction: 9.6 and $11.41 \%$ (Brito et al., 2005; Rostagno et al., 2011), whereas Brunelli et al. (2006) presented a much lower fat value $(0.60 \%)$ for defatted corn germ meal. This variation in fat content, both in defatted and fullfat CGM, depends on processing and corn variety. This also apply to corn itself, as shown by Rodrigues et al. (2001) and Albino et al. (1982), who analyzed corn composition and obtained 1.88 and $5.65 \%$ fat content, respectively. This represents a $66.54 \%$ variation, which may subsequently be reflected in CGM nutritional composition.

The observed gross energy value is 1.59 higher than that reported by Rostagno et al. (2011), of $4250 \mathrm{kcal} /$ $\mathrm{kg}$. This difference results from the EE level of CGM, in which each gram of lipids supplies and average of 8.5 cal, and therefore, presents higher energy density.

Coefficients of digestibility and AME and AMEn contents of the diets may explain the energy utilization of specific feedstuffs. In the present study, EE content was the main determining factor. The experimental feeds presented 13.55 and $17.72 \%$ EE with the dietary inclusion of 20 and 30\% CGM, respectively.

The layers fed the reference diet presented higher dry matter intake because that diet was balanced and contained less fat, differently from the other diets, which contained large amounts of CGM and high EE content. Feed intake was lower when CGM was fed. According to Mateos \& Sell (1981), fat-rich diets promote slower feed passage rate. Increased fatty acid ingestion activates hormones that slow down peristaltic movements, increasing the time the digesta remains in the digestive system and promoting the perception of satiety (Macari et al., 2002), thereby reducing feed intake.

The lower CAMDM of the feeds with CGM inclusion may be attributed to the higher fat content of this ingredient, which may have significantly influenced feed digestion and absorption. The higher coefficient of metabolizability of the reference diet is related to its lower fat content compared with the CGM diets.
Fat content also significantly influenced CAMDM, CAMEE, and CAMGE, with the feeds containing CGM presenting lower digestibility values and higher AME and AMEn content. Fatty acids have very diverse chemical structures that directly affect their digestibility, such as degree of saturation and chain size. Fat digestibility is also affected by the concentration of free fatty acids in the digesta, and animal factors, including maturity of the gastrointestinal tract and intestinal villus status. Wiseman \& Salvador (1991) reported that the combination of a high concentration of saturated fatty acids and free fatty acids (FFA) reduced ether extract digestibility and metabolizable energy content. High FFA concentrations reduce the formation of micelles in the small intestine, consequently impairing fat absorption. The saturation of lipid-absorbing proteins in the small intestine may have affected digestibility, as the CGM diets had high EE content.

Despite the lack of significant differences in EMA levels and in the coefficients of dry matter and ether extract digestibility, further research should be carried out using lower CGM inclusion levels to verify if the levels of 20 and $30 \%$ are indeed the most adequate. However, despite of the lack of statistical difference between 20 and 30\% CGM inclusion levels, CMAEE and CMAEB tended to decrease as CGM level increased.

\section{CONCLUSIONS}

The evaluated CGM presented the following chemical composition: $96.39 \%$ dry matter, $49.48 \%$ ether extract, $1.87 \%$ ashes, $7.243 \mathrm{kcal} / \mathrm{kg}$ gross energy, $11.48 \%$ protein, $0.19 \%$ methionine, $0.21 \%$ cystine, $0.48 \%$ lysine, $0.40 \%$ threonine, $0.72 \%$ arginine, $0.35 \%$ isoleucine, $0.83 \%$ leucine, $0.57 \%$ valine, and $0.37 \%$ histidine, on as-fed basis. Mean AME, AMEn, CAMDM, and CAMGE of the evaluated CGM were 4,578 and $4,548 \mathrm{kcal} / \mathrm{kg}, 4,723$ and $4,372 \mathrm{kcal} / \mathrm{kg}$, 64.95 and $61.86 \%$, respectively.

\section{ACKNOWLEDGEMENTS}

The authors thank Corn Products do Brasil for donating the corn germ meal and the company Evonik for the analyses of CGM amino acids.

\section{REFERENCES}

Associação Brasileira das Industrias do Milho. Milho: o cereal que enriquece a alimentação humana. 2010 [retrieved 2012 Mar 3]. Available at: http://www.abimilho.com.br.

Albino LFT, Ferreira AS, Fialho. Determinação dos valores de energia metabolizável e matéria seca aparente metabolizável de alguns 
alimentos. Revista da Sociedade Brasileira de Zootecnia 1982; 11(2):207-221

Andreotti MDO, Junqueira OM, Barbosa MJB, Cancherini LC, Araújo LF, Rodrigues EA. Tempo de trânsito intestinal, desempenho, característica de carcaça e composição corporal de frangos de corte alimentados com rações isoenergéticas formuladas com diferentes níveis de óleo de soja. Revista Brasileira de Zootecnia 2004;33:870-879.

Brito AB, Stringhini JH, Cruz CP, Xavier SAG, Leandro NSM, Café MB. Efeito do gérmen integral de milho sobre o desempenho e rendimento de carcaça de frangos de corte. Arquivo Brasileiro de Medicina Veterinária e Zootecnia 2005;57:241-249.

Brum PARD, Zanotto DL, Lima GJMMD, Viola ES. Composição química e energia metabolizável de ingredientes para aves. Pesquisa Agropecuária Brasileira 2000;35:995-1002

Brunelli SR, Pinheiro JW, Silva CAD, Fonseca NAN, Oliveira DDD, Cunha GE, Souza LFAD. Inclusão de farelo de gérmen de milho desengordurado na alimentação de frangos de corte. Revista Brasileira de Zootecnia 2006;35:1349-1358

Hill FW, Anderson DL. Comparison of metabolizable energy and productive energy determinations with growing chicks. The Journal of Nutrition 1958;64(4):587-603

Lima MB, Rabelo CBV, Silva EP, Lima RB, Arruda EMF, Albino LFT. Effect of broiler chicken age on ileal digestibility of corn germ meal. Acta Scientiarum. Animal Sciences 2012; 34(2):137-141.

Lima SBPD. Avaliação nutricional de co-produtos do milho para frango de corte caipira [mestrado]. Recife (PE): Universidade Federal Rural de Pernambuco; 2007

Macari M, Furlan RL, Gonzales E. Fisiologia aviária aplicada a frangos de corte. Jaboticabal: FUNEP; 2002
Mateos GG, Sell JL. Influence of Fat and Carbohydrate Source on Rate of Food Passage of Semipurified Diets for Laying Hens. Poultry Science $1981 ; 60(9): 2114-2119$

Matterson LD, Potter LM, Stutz MW. The Metabolizable energy of feed ingredients for chickens. Storrs: Agricultural Experiment Station, University of Connecticut; 1965. 11

Penz JR AM, Vieira SL. Características nutricionais da dieta de primeira semana de pintos. Anais do $3^{\circ}$ Simpósio Goiano de Avicultura; 1992 Abr 9-11; Goiana, Goías. Brasil: UFG; 1992. p.21 - 28

Rodrigues PB, Rostagn HS, Albino LFT, Gomes PC, Barboza WA, Santana RT. Valores energéticos do milheto, do milho e subprodutos do milho, determinados com frangos de corte e galos adultos. Revista Brasileira de Zootecnia 2001;30:1767-1778.

Rostagno HS, Albino LFT, Donzele JL, Lopes DC, Gomes PC, Oliveira R F de, et al. Tabelas brasileiras para aves e suínos: composição de alimentos e exigências nutricionais. Viçosa: UFV/DZO; 2005

Rostagno HS, Albino LFT, Donzele JL, Gomes PC, Oliveira RF de, Lopes DC, et al.Tabelas brasileiras para aves e suínos: composição de alimentos e exigências nutricionais. Viçosa: UFV / DZO; 2011

Statistical Analysis System. SAS/ACCESS 9.1 interface to PeopleSoft: user's guide. Cary: SAS Pub.; 2004.

Silva DJ, Queiroz AC. Análise de alimentos: métodos químicos e biológicos. Viçosa: Universidade Federal de Viçosa; 2006.

Wiseman J, Salvador F. The influence of free fatty acid content and degree of saturation on the apparent metabolizable energy value of fats fed to broilers. Poultry Science 1991;70(3):573-82. 